\title{
The position generator approach to social capital research: measurements and results
}

Link to publication record in Manchester Research Explorer

\section{Citation for published version (APA):}

$\mathrm{Li}, \mathrm{Y}$., \& Verhaeghe, P. (2015). The position generator approach to social capital research: measurements and results. In Y. Li (Ed.), The Handbook of Research Methods and Applications on Social Capital (pp. 166-186). Edward Elgar Publishing Ltd.

\section{Published in:}

The Handbook of Research Methods and Applications on Social Capital

\section{Citing this paper}

Please note that where the full-text provided on Manchester Research Explorer is the Author Accepted Manuscript or Proof version this may differ from the final Published version. If citing, it is advised that you check and use the publisher's definitive version.

\section{General rights}

Copyright and moral rights for the publications made accessible in the Research Explorer are retained by the authors and/or other copyright owners and it is a condition of accessing publications that users recognise and abide by the legal requirements associated with these rights.

\section{Takedown policy}

If you believe that this document breaches copyright please refer to the University of Manchester's Takedown Procedures [http://man.ac.uk/04Y6Bo] or contact uml.scholarlycommunications@manchester.ac.uk providing relevant details, so we can investigate your claim.

\section{OPEN ACCESS}




\section{The position generator approach to social capital research: measurements and results Pieter-Paul Verhaeghe and Yaojun Li}

\section{INTRODUCTION}

In the last three decades social capital has become a popular research concept in social sciences. In its network-resources approach, social capital can be defined as the resources embedded in social networks that can be accessed or used by individuals for instrumental actions (Bourdieu, 1986; Portes, 1998; Völker and Flap, 1999; Lin, 2001; Li, 2010). Because this perspective focuses on resources, it illuminates how social capital produces and reproduces social inequalities. Along with the growing popularity of the social capital concept, multiple instruments have been developed to measure it, such as name generators, resource generators and position generators (Van der Gaag, 2005; Lin and Erickson, 2008). Of particular note amongst these is the position generator approach developed by Lin (Lin and Dumin, 1986; Lin, 2001). As compared with the name or the resource generators, position generators have the advantage that they are easy to use, have high response rates and short question times, are applicable to different research settings and contexts and, unlike most name generators, are unbiased towards strong ties. Position generators map network members' occupational positions by asking respondents whether they know anyone in their social network with an occupation from a limited and yet representative list of occupations (Lin and Dumin, 1986; Lin et al., 2001; Van der Gaag, 2005). These occupational positions are considered to be good indicators of the resources embedded in a social network.

Over time a wide array of measures has been developed from network members' occupational positions, generated through the position generator. These measures differ in the underlying social capital concepts they want to measure (such as volume or heterogeneity of network resources) and in the socioeconomic indices used to assess the resources that are assumed to be available or derivable from the occupational positions (such as occupational prestige/status scores or social class classifications). Moreover, some measures are more popular in social capital research than others. Most scholars are guided in their choice between position generator measures by practical arguments (for example, number of occupational items) and/or by findings from previous studies (and thus unconsciously by popularity issues). Because different position generator measures imply different theoretical departing points, it would be interesting to examine whether conceptually different measures result in different findings or not. Researchers may wish to know to what extent their findings would have been different if other measures had been used. Previous studies have tested the reliabilities of several position generator measures across time (Erickson, 2004; Angelusz and Tardos, 2008) and across different occupational lists (Verhaeghe et al., 2013a). However, the extent to which these different

\section{File supplied to Li - Not for distribution}


measures would result in different findings and the implications of such different findings have not been tested.

This study gives an overview of the existing research on position generator measures, tracks their popularity over time, and examines the extent to which research results would differ due to the use of different position generator measures. We focus on two research topics: (1) the association between social capital and socioeconomic attainment; and (2) the association between social capital and self-rated health. The relationship between social capital on the one hand and socioeconomic attainment and health on the other lies, among others, at the very heart of the social capital research paradigm, and our choice of these indicators will hopefully provide an appropriate test of the position generator approach. We examine these topics with two large-scale surveys: the Taking Part Surveys of England and the Netherlands Longitudinal Life Course Study. By examining the outcomes in these two domains and using data from the two social contexts, we aim to enhance the generalizability of this study's findings.

\section{THEORETICAL REVIEW}

\section{Position Generator Measures}

Survey researchers using the position generator method ask respondents whether they know anyone in their social network with an occupation from a limited list of different occupations representative of the national population (Lin and Dumin, 1986; Lin et al., 2001; Van der Gaag, 2005). Sometimes further information is obtained about the relationships of the contacts to the respondent, such as acquaintances, friends or family members who hold such occupations. The result is a number of occupations accessed by the respondent through his/her social network. The position generator instrument makes two assumptions. First, it presumes that the distribution of resources in a society is adequately reflected in its occupational structure. The position generator thus takes an 'employment-aggregate' approach to social stratification (Crompton, 2008). Secondly, it presupposes that knowing anyone with a certain occupation implies having access to the resources associated with that occupation.

Using responses to the position generator items, one can quantify social network resources through multiple measures. We have found six types of such measure in the literature. They differ from one another in their conceptualization of social capital and/ or in their perspective on social stratification. ${ }^{1}$ An overview of these measures is shown in Table 10.1.

The most straightforward measure is the volume of network resources. This measure simply counts the total number of contacts the respondent knows who have occupations from the position generator lists (Van der Gaag, 2005). The underlying idea is that the more ties that are accessible through the social network, the better. The measure makes no distinction between different kinds of occupations and ignores, consequently, the unequal distribution of resources in society. It is strongly related to a person's network size: people with more relatives, friends or acquaintances may know more people with occupations on the position generator list (Van der Gaag et al., 2008).

However, not all occupational resources are equally useful. For some purposes, it is

\section{File supplied to Li - Not for distribution}


Table 10.1 Overview of six types of position generator measures

\begin{tabular}{|c|c|c|}
\hline $\begin{array}{l}\text { Name of position generator } \\
\text { measure }\end{array}$ & $\begin{array}{l}\text { Perspective on social network } \\
\text { resources }\end{array}$ & $\begin{array}{l}\text { Perspective on social } \\
\text { stratification }\end{array}$ \\
\hline Volume of network resources & The more, the better & $\begin{array}{l}\text { No stratificational } \\
\text { perspective }\end{array}$ \\
\hline $\begin{array}{l}\text { Average occupational prestige/ } \\
\text { status of network resources }\end{array}$ & The higher the average, the better & $\begin{array}{l}\text { Occupational prestige/ } \\
\text { status }\end{array}$ \\
\hline $\begin{array}{l}\text { Highest occupational prestige/ } \\
\text { status of network resources }\end{array}$ & $\begin{array}{l}\text { The higher the highest reach, the } \\
\text { better }\end{array}$ & $\begin{array}{l}\text { Occupational prestige/ } \\
\text { status }\end{array}$ \\
\hline $\begin{array}{l}\text { Range in occupational prestige/ } \\
\text { status of network resources }\end{array}$ & The more diverse, the better & $\begin{array}{l}\text { Occupational prestige/ } \\
\text { status }\end{array}$ \\
\hline $\begin{array}{l}\text { Occupational prestige/status } \\
\text { component scores of network } \\
\text { resources }\end{array}$ & $\begin{array}{l}\text { Network resources are } \\
\text { multidimensional }\end{array}$ & $\begin{array}{l}\text { Occupational prestige/ } \\
\text { status }\end{array}$ \\
\hline Social class-based measures & $\begin{array}{l}\text { Qualitative distinctions between } \\
\text { types of network resources }\end{array}$ & Social class typology \\
\hline
\end{tabular}

not the quantity but the quality that counts. Therefore, the five other types of position generator measures make use of socioeconomic indices to differentiate between occupations (Van der Gaag, 2005; Lin et al., 2001; Verhaeghe et al., 2013a). Four measurement types are based on continuous occupational prestige or status scales and the fifth on categorical social class typologies. In addition, each of these highlights a different component of social capital.

Occupational prestige scales refer to the evaluation of occupational standing in society (Ganzeboom and Treiman, 1996). The structural theory of prestige determination as elaborated by Treiman (1977) posits that complex societies have similar occupational prestige hierarchies and that within each society there is a remarkable consensus concerning this hierarchy. In his theory of social resources, Lin (1982) considered occupational prestige as an indication of universally valued resources, such as wealth, power and status. In their seminal study on the position generator, Lin and Dumin (1986) used occupational prestige scores to assess the resources associated with the network members' occupational positions. Since then, most researchers in the field have drawn on occupational prestige scales to construct position generator measures.

Occupational status scales, in contrast, concern the attributes of occupations that convert a person's education into an income (Ganzeboom et al., 1992; Ganzeboom and Treiman, 1996). Although occupational status scores were initially developed in order to generalize prestige scores for all occupations (Duncan, 1961), they do not involve subjective evaluations such as prestige scales (Ganzeboom et al., 1992). They are constructed by computing a weighted sum of the average education and the average income of occupational groups. Because socioeconomic status scores refer to human resources and economic rewards rather than to prestige, they are believed to be more convenient in indicating the resources that go with a network member's occupation (Van der Gaag et al., 2008). Nevertheless, only a small number of position generator studies make use of occupational status scores to assess the network resources. Both occupational prestige and status rankings are known as 'gradational measures'. They reflect a functionalist

\section{File supplied to Li - Not for distribution}


perspective on social stratification in which unequal rewards are considered as differentially useful because they provide a socially supported structure of incentives for doing different kinds of work (Davis and Moore, 1945).

With these occupational prestige or status scales, four types of position generator measures can be constructed. They differ in their conceptualization of social capital. The mean occupational prestige/status of network resources is calculated by dividing the sum of the prestige/status scores of accessed occupations by the total number of accessed occupations. The underlying idea of this measure is that occupations with higher prestige/status are associated with more and better resources and that it is the quality of the overall social network that matters for accomplishing goals. The highest occupational prestige/status of network resources is assessed by looking at the highest prestige/status of the accessed occupations. This measure follows the idea that the most powerful and best resources are located within positions with the highest prestige/status. In contrast to the average-measure, however, this measure implies that one needs to know only one network member with high occupational prestige/status to access these resources. It focuses on the 'upper reachability' of a social network. The range in occupational prestige/status of network resources is constructed by calculating the difference between the highest and lowest occupational prestige scores of the accessed occupations. This measure stresses the strength of resource heterogeneity: the more diverse the social network resources, the better. Finally, many studies construct a composite (component) prestige/status score of network resources by using the weighted sum of three position generator measures: (1) volume of network resources; (2) highest occupational prestige/ status of network resources; and (3) range in occupational prestige/status of network resources. This composite prestige/status measure intends to incorporate several social capital-components (volume, upper reachability and resource heterogeneity) and reflects a multidimensional perspective on social network resources.

In addition to occupational prestige/status scales, social class typologies can also be used to differentiate between network members' occupational positions. A social class approach requires the classification of occupations into a number of clearly distinguishable categories by means of multiple dimensions (Ganzeboom et al., 1992). These dimensions focus on the unequal relations of people to economic or human capital resources (for example ownership of means of production, skill level and supervision). These economic and cultural resources are allocated among social classes with a high heterogeneity between the classes and a high homogeneity within them. Therefore, it might be argued that the resources associated with the network members' occupations are best measured through a class approach.

Although Lin and Dumin (1986) also used a social class classification in their study to assess network resources, few other position generator studies have used a class perspective to construct position generator measures. Among those that do make categorical distinctions between occupations, few refer explicitly to social class theories (Enns et al., 2008; Côté and Erickson, 2009). Each of these studies, however, counts the number of accessed occupations in different social classes or occupational categories (most often the 'salariat', 'white collar', 'working class' or 'blue-collar' classes). These social classbased position generator measures refer to different types of network resources (such as salariat and working-class network resources). The underlying idea is that qualitative distinctions should be made between different kinds of network resources. It is no longer

\section{File supplied to Li - Not for distribution}


a matter of 'more or less' or 'better or worse' resources, but rather a matter of 'different kinds' of resources. Moreover, when theoretically driven distinctions are made between different classes of occupational resources, these position generator studies follow a conflict perspective on social stratification.

\section{Popularity of Position Generator Measures}

Some position generator measures are more popular in social capital research than others. We conducted a literature review of position generator studies in order to examine the popularity of the six types of position generator measures over time. On $15 \mathrm{March}$ 2012, we searched for position generator studies in the databases 'Sociological abstracts' and 'Google scholar' with the search term 'position generator'. To be included in the review, three criteria had to be fulfilled: the study has to: (1) be published; (2) report original findings with one or more position generator measures; and (3) be transparent and clear about the construction of the position generator measure(s). In total, 78 position generator studies met these criteria.

From the overview as shown in Table 10.2, a few conclusions can be drawn. Firstly, since the seminal study of Lin and Dumin in 1986, the position generator instrument has experienced a growing popularity, especially after the turn of the century, corresponding to the exponential growth of studies in the civic tradition (Field, 2008: 5). Secondly, the most popular position generator measure is the 'volume of network resources', followed by measures on 'average prestige/status', 'highest prestige/status' and 'range in prestige/ status'. The component prestige/status score and the social class-based measures are the least used. Although less clear from Table 10.2, it appeared that 41 studies used one or more position generator measures that are based on occupational prestige or status.

That the volume-measure is most widely used is probably due to its straightforwardness in calculation and ease of interpretation. It is, however, remarkable that social classbased measures are considerably less popular than occupational prestige/status-based measures although both types of measures are used in Lin and Dumin (1986). This could be due to the declining popularity of class analysis in general. In the United States, socioeconomic stratification research has always been dominated by occupational prestige

Table 10.2 Popularity of six types of position generator measures over time

\begin{tabular}{lccccccc}
\hline & & \multicolumn{5}{c}{ Number of position generator studies that use } \\
\cline { 3 - 8 } & Total & Volume & $\begin{array}{c}\text { Average } \\
\text { prestige/ } \\
\text { status }\end{array}$ & $\begin{array}{c}\text { Highest } \\
\text { prestige/ } \\
\text { status }\end{array}$ & $\begin{array}{c}\text { Range in } \\
\text { prestige/ } \\
\text { status }\end{array}$ & $\begin{array}{c}\text { Component } \\
\text { prestige/ } \\
\text { status score }\end{array}$ & $\begin{array}{c}\text { Social } \\
\text { class-based } \\
\text { measures }\end{array}$ \\
\hline $1985-1990$ & 1 & 1 & 1 & 1 & 1 & 0 & 1 \\
$1991-1995$ & 0 & 0 & 0 & 0 & 0 & 0 & 0 \\
$1996-2000$ & 3 & 2 & 1 & 2 & 2 & 0 & 2 \\
$2001-2005$ & 8 & 6 & 1 & 2 & 2 & 3 & 2 \\
$2006-2010$ & 48 & 33 & 10 & 11 & 12 & 12 & 9 \\
$2011-2012$ & 18 & 14 & 7 & 4 & 4 & 1 & 1 \\
Total & 78 & 56 & 20 & 20 & 21 & 16 & 15 \\
\hline
\end{tabular}


or status scales. In Europe, and especially in Britain, both social class and occupational prestige/status scales are used although the class approach is adopted more often.

\section{Different Position Generator Measures, Different Results?}

We have, in the foregoing, shown that the six types of position generator measure differ in their theoretical perspectives on social network resources and social stratification, and in their popularity in social capital research. The question is: does it matter? In other words, do theoretically different position generator measures result in different findings and capture different aspects of social reality, and are some measures more popular because they result in more pronounced effects? We examine, in the following, these questions with respect to two general domains of life chances: socioeconomic attainment and self-rated health.

Quite a few studies have shown positive associations between several position generator measures and different indicators of socioeconomic attainment (Lin and Dumin, 1986; Erickson, 1996; Lin, 1999; Völker and Flap, 1999; Li et al., 2008). People with many, heterogeneous and/or socioeconomically more advantageous network resources are more likely to be employed and to have jobs in the salariat class, with higher earnings and a higher occupational prestige/status. Network members could help people in their career through multiple mechanisms, such as providing labour market and job information, encouraging them to search for (better) jobs, putting in a good word with an employer or directly hiring them (Green et al., 1999; Elliott, 2001; McDonald et al., 2009; Verhaeghe et al., 2013b).

In addition, research has shown significant associations with several health outcomes. People with many, diverse and/or socioeconomically advantageous network resources are more likely to have good or very good self-rated health (Carpiano and Hystad, 2011; Moore et al., 2011; Song and Lin, 2009; Han et al., 2012; Verhaeghe et al., 2012; Verhaeghe and Tampubolon, 2012) and are less likely to report depressive symptoms (Song and Lin, 2009; Song, 2011) and to be overweight or obese (Moore et al., 2009). Network members' resources could affect health through several pathways (Kawachi and Berkman, 2001; Song, 2011; Verhaeghe et al., 2012; Verhaeghe and Tampubolon, 2012). Neo-materialist explanations emphasize the (lack of) access to health-related resources through network members (such as money for healthy food, access to health care or health insurance) or exposure to socioeconomic stressors (such as job loss or mortgage delinquencies of network members). From a lifestyle perspective (Cockerham, 2005; Abel and Frohlich, 2012), one could argue that because people are embedded and socialized in networks, network members' resources either empower or constrain people's choice of health-related behavioural options (for example, physical activity, diet, alcohol and tobacco consumption).

\section{DATA AND METHODOLOGY}

\section{Data}

We use data from large-scale surveys collected in two different social contexts: the Taking Part Surveys of England (TPSE) and the Netherlands Longitudinal Life Course

\section{File supplied to Li - Not for distribution}




\section{Handbook of research methods and applications in social capital}

Study (NELLS). The Taking Part Surveys of England are representative samples of the non-institutionalized population in England for people aged 16 or over (Aust and Vine, 2007; Williams, 2007, 2008). We pooled data from the 2006/2007 and 2007/2008 series, which consist of 49894 face-to-face interviews. Response rates were 55 and 59 per cent. We used the first wave of the Netherlands Longitudinal Life Course Study (De Graaf et al., 2010a, 2010b). This survey is a representative sample of the Dutch population aged 15-45, with an oversample of first and second generation immigrants from Turkey and Morocco. The survey was conducted between December 2008 and May 2010 and consisted of two parts: a face-to-face interview and a self-completion questionnaire. The overall response of the survey was 52 per cent. Response was highest for the Dutch (56 per cent), lower for the Turks (50 per cent) and lowest for the Moroccans (46 per cent). In total, 5312 respondents were interviewed.

\section{Position Generator Variables}

In the TPSE, respondents were asked whether they happen to know anyone socially, including friends and relatives, who has any of the jobs from a list of 11 occupations. All 11 occupations are salient in British society and range from factory worker to university/college lecturer (Table 10.3). In the NELLS, respondents were asked whether they have friends, relatives or acquaintances who have any of the occupations from a list of 20 occupations. Respondents were instructed to name only people 'whom they know outside the work setting'. These occupations were common in Dutch society and range from lorry or truck driver to physician (Table 10.4).

For both datasets, we constructed 12 position generator variables. First, we calculated the volume of network resources by counting the number of different occupations accessed by respondents. This measure ranges in the TPSE from 0 to 11 and in

Table 10.3 Occupational prestige and status scores, social class positions, and distribution of the occupations in the position generator instrument in the TPSE data $(N=45985)$

\begin{tabular}{lcclc}
\hline Occupational Item & $\begin{array}{c}\text { Occupational } \\
\text { Prestige }\end{array}$ & $\begin{array}{c}\text { Occupational } \\
\text { Status }\end{array}$ & Social Class Position & $\%$ \\
University/college lecturer & 78 & 77 & Higher salariat class & 27.7 \\
Solicitor & 71 & 82 & Higher salariat class & 30.9 \\
Bank or building society manager & 60 & 87 & Higher salariat class & 18.2 \\
Company secretary & 60 & 69 & Higher salariat class & 37.0 \\
Nurse & 54 & 43 & Lower salariat class & 48.0 \\
Clerical officer in national or & 37 & 45 & Routine clerical/sales & 25.4 \\
$\quad$ local government & 32 & 43 & Routine clerical/sales & 44.7 \\
Sales or shop assistant & 38 & 40 & Working class & 39.9 \\
Electrician & 33 & 39 & Working class & 23.1 \\
Postal worker & 33 & 24 & Working class & 33.6 \\
Factory worker & 32 & 30 & Working class & 21.1 \\
Bus or coach driver & & & &
\end{tabular}


Table 10.4 Occupational prestige and status scores, social class positions, and distribution of the occupations in the position generator instrument in the NELLS data $(N=4667)$

\begin{tabular}{lcclc}
\hline Occupational Item & $\begin{array}{c}\text { Occupational } \\
\text { Prestige }\end{array}$ & $\begin{array}{c}\text { Occupational } \\
\text { Status }\end{array}$ & Social Class Position & $\begin{array}{c}\% \\
\text { Known }\end{array}$ \\
\hline Physician or medical specialist & 78 & 88 & Higher salariat class & 30.9 \\
Lawyer or jurist & 73 & 85 & Higher salariat class & 26.9 \\
Director or manager director of a & 70 & 70 & Higher salariat class & 39.1 \\
$\quad$ company & 63 & 73 & Higher salariat class & 31.2 \\
Engineer & 62 & 69 & Higher salariat class & 31.0 \\
Accountant & 60 & 69 & Higher salariat class & 21.1 \\
Scientist or researcher & 51 & 71 & Higher salariat class & 50.4 \\
Computer operator & 61 & 69 & Lower salariat class & 54.0 \\
Teacher & 57 & 61 & Lower salariat class & 22.5 \\
Musician/artist/writer & 55 & 55 & Lower salariat class & 18.9 \\
Broker & 46 & 56 & Lower salariat class & 37.2 \\
Commercial sales representative & & & & \\
$\quad$ account manager & 46 & 53 & Lower salariat class & 29.5 \\
Foreman & 46 & 49 & Lower salariat class & 48.1 \\
Shop owner & 53 & 53 & Routine clerical/sales & 39.2 \\
Secretary & 44 & 38 & Routine clerical/sales & 44.8 \\
Nurse & 40 & 50 & Working class & 31.6 \\
Policeman & 40 & 37 & Working class & 49.5 \\
Car or electricity mechanic & 34 & 30 & Working class & 44.8 \\
Construction worker & 31 & 30 & Working class & 29.8 \\
Cook & 33 & 34 & Working class & 35.7 \\
Lorry or truck driver & & & & \\
\hline
\end{tabular}

the NELLS from 0 to 20 . In both datasets, only a limited proportion of respondents indicated that they do not know anyone in any of the listed occupations (13.6 and 5.3 per cent respectively).

Secondly, the occupational items were assigned occupational prestige and occupational status scores. Occupational prestige was assessed by the Standard Occupational Prestige Scale (Treiman, 1977) and occupational status was measured by the International SocioEconomic Index of occupational status (Ganzeboom et al., 1992). The prestige and status values were assigned using the transformation tools of Ganzeboom and Treiman (1996). Occupational prestige ranged in the TPSE from 32 (bus/coach driver or sales/ shop assistant) to 78 (university/college lecturer) and in the NELLS from 31 (cook) to 78 (physician). Occupational status ranged in the TPSE from 24 (factory worker) to 87 (bank or building society manager) and in the NELLS from 30 (cook or construction worker) to 88 (physician). Afterwards, we calculated both the mean occupational prestige of network resources and the mean occupational status of network resources by dividing the sum of, respectively, the occupational prestige and occupational status scores of accessed occupations by the total number of accessed occupations. Respondents who did not know anyone having one of the listed occupations were assigned a zero score.

\section{File supplied to Li - Not for distribution}




\section{Handbook of research methods and applications in social capital}

Thirdly, the highest occupational prestige and highest occupational status of network resources were measured by using the highest occupational prestige and status scores of accessed occupations respectively.

Fourthly, the range in occupational prestige and the range in occupational status of network resources were calculated by subtracting the lowest occupational prestige/status scores from the highest occupational prestige/status scores of accessed occupations.

Fifthly, the composite scores of network resources were calculated using the weighted sum of three indices: (1) volume of network resources; (2) highest occupational prestige/ status of network resources; and (3) range in occupational prestige/status of network resources. We made two versions of this: one based on occupational prestige scores and the other on occupational status scores. Weights for constructing the score were derived from a principal component analysis. In the TPSE, weights for the occupational prestige score were 0.91 volume +0.91 highest prestige +0.95 range in prestige; and for the occupational status score 0.87 volume +0.90 highest status +0.95 range in status. In the NELLS, weights for the occupational prestige score were 0.88 volume +0.90 highest prestige +0.96 range in prestige; and for the occupational status score 0.87 volume + 0.90 highest status +0.95 range in status.

Finally, occupational items are split up into social classes following Goldthorpe's (1987) class schema. In the NELLS, we differentiate between higher salariat (including higher-grade professionals, administrators, managers and large proprietors), lower salariat (including lower-grade professionals, administrators and managers) and occupations in routine clerical/sales and the working class (including routine non-manual employees, skilled, semi-skilled and unskilled manual workers). Subsequently, we count the number of accessed occupations in these classes, resulting in three position generator variables: higher salariat network resources, lower salariat network resources, and routine and working-class network resources. In the TPSE, there are not enough occupational items to differentiate between higher and lower salariat class occupations. Therefore, we only distinguish between salariat class occupations and routine and working-class occupations. Afterwards, we count again the number of accessed occupations in these two classes, resulting in two position generator variables: salariat class network resources, and routine and working-class network resources.

\section{Dependent and Explanatory Variables}

We examine the associations of these 12 position generator variables with the own social class position and self-rated health. In both datasets, we made a distinction between people who are member of the salariat class and those who are not. Following Goldthorpe's (1987) class schema again, salariat class occupations include higher- and lower-grade professionals, administrators, managers and large proprietors; highergrade technicians; and supervisors of non-manual employees. Research has shown that the deepest class inequalities in social capital are between an apparently engaged and involved salariat class and an apparently increasingly disengaged non-salariat class (Savage et al., 2006; Li et al., 2003). In both TPSE and NELLS, the respondent's class position is measured on the basis of his or her employment status and current (or last main) job.

To assess self-rated health, respondents in both surveys were asked to rate their

\section{File supplied to Li - Not for distribution}


health in general. Response categories ranged in the TPSE from 'very poor', 'poor', 'fair', 'good', to 'very good'; and in the NELLS from 'poor', 'fair', 'good', 'very good' to 'excellent'.

We control for five background factors in the multivariate analyses: gender, age, marital status, ethnicity, and educational attainment. In the TPSE 43.8 per cent were males and 56.2 per cent were females, whereas in the NELLS 47 per cent were males and 53 per cent were females. In both datasets, we restrict the samples to respondents who are 18 years or older. The highest age in the TPSE was 99 years and in the NELLS 49 years. We differentiated between single, married or cohabiting people, and people who are separated, divorced or widowed. In the NELLS, we made a distinction between nine ethnic categories based on the countries of birth of the respondent and both parents: 'Dutch' (49.8 per cent); 'first generation Moroccan' (15.3 per cent); 'second generation Moroccan' (5.6 per cent); 'first generation Turk' (15.4 per cent); 'second generation Turk' (5.7 per cent); 'first generation non-western immigrant' ( 2.8 per cent); 'second generation non-western immigrant' (1.2 per cent); 'first generation western immigrant' (1.7 per cent); and 'second generation western immigrant' ( 2.5 per cent). In the TPSE, ethnicity was assessed by self-definition with eight categories: 'White' ( 89.8 per cent); 'Mixed' (1.0 per cent); 'Indian' (2.3 per cent); 'Pakistani or Bangladeshi' (1.9 per cent); 'Black African' (1.7 per cent); 'Black Caribbean' (1.5 per cent); 'Chinese' ( 0.3 per cent); and a category for the rest (1.6 per cent). Because we do not know the countries of birth in the TPSE, we are not able to distinguish between first and later generations of immigrants. In both datasets, four educational categories were distinguished: tertiary; higher secondary; lower secondary; and primary or no education.

\section{Analyses}

We examine the associations of the six types of position generator measures with our two dependent variables: salariat class position and self-rated health. We perform logistic regressions of class position and ordinal logistic regressions of self-rated health. For each sample, we ran 10 models for each dependent variable. Each model contains one position generator variable: model 1 (volume of network resources); model 2 (average prestige); model 3 (average status); model 4 (highest prestige); model 5 (highest status); model 6 (range in prestige); model 7 (range in status); model 8 (composite prestige score); model 9 (composite status score); and model 10 (three class-based position generator variables). Moreover, each model controls for the five background factors: gender; age; marital status; ethnicity; and educational attainment. The models of self-rated health additionally control for the respondent's class position.

We compare the 10 models in three ways. First, we look at the significance level and direction of the unstandardized coefficients of the position generator variables. However, in order to compare the relative strength of the coefficients across the models, we standardize all independent variables. Subsequently, we compare the standardized coefficient of the position generator variables. Finally, we compare the models' goodness of fit, using Akaike Information Criteria (AIC) and Bayesian Information Criteria (BIC). The smaller the AIC/BIC values, the better the goodness of fit. These model estimates extend the method of maximum likelihood fitting by discouraging the model overfitting.

\section{File supplied to Li - Not for distribution}




\section{RESULTS}

\section{Descriptive Statistics and Missing Data}

Out of the original TPSE sample of 49894 participants, 49752 persons answered the position generator questions. We dropped all respondents who were younger than 18 at the time of the interview since most of them were still at school $(\mathrm{N}=1103)$, or who did not know or refused to say their age $(\mathrm{N}=185)$. From this, another 2479 observations were dropped from analyses due to missing data on gender, marital status, ethnicity, educational attainment, and social class position. On the resulting sample of 45985 observations (sample 1), all analyses on the associations between social capital and class position were performed. However, due to missing data on the variables about self-rated health $(\mathrm{N}=45)$, analyses with this outcome variable were based on a sample of 45940 (sample 2). Table 10.5 shows descriptive statistics of all variables used here.

From the original NELLS sample of 5312 participations, all respondents but one answered the position generator questions. We dropped all respondents who were younger than $18(\mathrm{~N}=429)$. In addition, 216 observations were dropped due to missing data on gender, marital status, ethnicity, educational attainment, and social class position. On the resulting sample of 4667 respondents (sample 3), all analyses on the associations between social capital and class position were performed. Because of missing data on self-rated health $(\mathrm{N}=375)$, analyses with this outcome were based on a sample of 4292 observations (sample 4). Table 10.6 reports descriptive statistics of all used variables in the NELLS samples.

From the correlation matrices in Table 10.7, we can see that a number of position generator variables are highly correlated. First, the variables based on the occupational prestige of network resources (mean, highest, range and component) are very strongly correlated with those based on the occupational status. In other words, it does not matter very much whether position generator variables are constructed with occupational prestige scales or with occupational status scales. Secondly, the volume, highest, and range measures are strongly correlated with the composite measures, which is as expected given their numerical dependence.

From the multivariate logistic regression models on class membership in Tables 10.8 and 10.9 , we can see that almost all position generator variables are positively associated with the salariat class, after taking the background factors into account (net odds ratios $>1$ ). People with more social ties, with ties in high prestige/status and/or different jobs, especially in (higher) salariat class positions, are more likely to find themselves in a salariat occupation (one could equally argue that people in salariat positions are more likely to have more ties and to have ties in higher places). However, in both England and the Netherlands having routine or working-class network resources is negatively related with being situated in the salariat class (net odds ratios are respectively 0.87 and 0.91 ). From the standardized odds ratios, we see that the strongest associations between social capital and class position are shown with class-based position generator measures, followed by measures capturing the average occupational prestige/status and the highest occupational prestige/status of network resources. This pattern is confirmed when we look at the Akaike and Bayesian Information Criteria (AIC and BIC). The models with

\section{File supplied to Li - Not for distribution}


Table 10.5 Descriptive statistics of Taking Part Surveys of England samples

\begin{tabular}{|c|c|c|c|}
\hline Sample $1(\mathrm{~N}=45985)$ & Mean & S.D. & Range \\
\hline \multicolumn{4}{|l|}{ Position Generator Variables } \\
\hline Volume of network resources & 3.51 & 2.66 & $0-11$ \\
\hline Average occupational prestige of network resources & 41.04 & 18.66 & $0-78$ \\
\hline Average occupational status of network resources & 43.61 & 20.58 & $0-87$ \\
\hline Highest occupational prestige of network resources & 53.97 & 25.66 & $0-78$ \\
\hline Highest occupational status of network resources & 58.83 & 29.30 & $0-87$ \\
\hline Range in occupational prestige of network resources & 22.31 & 18.08 & $0-46$ \\
\hline Range in occupational status of network resources & 28.02 & 23.37 & $0-63$ \\
\hline Component occupational prestige score of network resources & 0.00 & 1.00 & $-1.67-1.83$ \\
\hline Component occupational status score of network resources & 0.00 & 1.00 & $-1.61-1.90$ \\
\hline Salariat class network resources & 1.62 & 1.46 & $0-5$ \\
\hline Routine and working-class network resources & 1.89 & 1.64 & $0-6$ \\
\hline \multirow[t]{2}{*}{ Age } & 50.68 & 17.98 & $18-99$ \\
\hline & $\mathrm{N}$ & $\%$ & \\
\hline \multicolumn{4}{|l|}{ Social Class Position } \\
\hline Non-salariat class & 21558 & 68.6 & \\
\hline Salariat class & 14427 & 31.4 & \\
\hline \multicolumn{4}{|l|}{ Gender } \\
\hline Male & 20114 & 43.7 & \\
\hline Female & 25871 & 56.3 & \\
\hline \multicolumn{4}{|l|}{ Marital Status } \\
\hline Single & 8909 & 19.4 & \\
\hline Married or cohabiting & 25944 & 56.4 & \\
\hline Divorced & 11132 & 24.2 & \\
\hline \multicolumn{4}{|l|}{ Ethnicity } \\
\hline White & 41276 & 89.8 & \\
\hline Mixed & 455 & 1.0 & \\
\hline Indian & 1049 & 2.3 & \\
\hline Pakistani or Bangladeshi & 876 & 1.9 & \\
\hline Black African & 794 & 1.7 & \\
\hline Black Caribbean & 676 & 1.5 & \\
\hline Chinese & 125 & 0.3 & \\
\hline Other ethnicity & 734 & 1.6 & \\
\hline \multicolumn{4}{|l|}{ Educational Attainment } \\
\hline Primary or no education & 12679 & 27.6 & \\
\hline Lower secondary education & 1072 & 23.3 & \\
\hline Higher secondary education & 12378 & 26.9 & \\
\hline Tertiary education & 10208 & 22.2 & \\
\hline Sample $2(\mathrm{~N}=45940)$ & $\mathrm{N}$ & $\%$ & \\
\hline \multicolumn{4}{|l|}{$\overline{\text { Self-Rated Health }}$} \\
\hline Very poor & 707 & 1.54 & \\
\hline Poor & 2834 & 6.17 & \\
\hline Fair & 10221 & 22.3 & \\
\hline Good & 18899 & 41.1 & \\
\hline Very good & 13279 & 28.9 & \\
\hline
\end{tabular}


178 Handbook of research methods and applications in social capital

Table 10.6 Descriptive statistics of the Netherlands Longitudinal Life Course Study
samples

\begin{tabular}{|c|c|c|c|}
\hline Sample $3(\mathrm{~N}=4667)$ & Mean & S.D. & Range \\
\hline \multicolumn{4}{|l|}{ Position Generator Variables } \\
\hline Volume of network resources & 7.19 & 4.5 & $0-20$ \\
\hline Average occupational prestige of network resources & 47.74 & 12.9 & $0-78$ \\
\hline Average occupational status of network resources & 51.91 & 14.8 & $0-88$ \\
\hline Highest occupational prestige of network resources & 63.70 & 18.6 & $0-78$ \\
\hline Highest occupational status of network resources & 71.25 & 21.4 & $0-88$ \\
\hline Range in occupational prestige of network resources & 29.64 & 14.9 & $0-47$ \\
\hline Range in occupational status of network resources & 38.05 & 18.5 & $0-58$ \\
\hline Component occupational prestige score of network resources & 0.00 & 1.0 & $-2.56-1.73$ \\
\hline Component occupational status score of network resources & 0.00 & 1.0 & $-2.57-1.71$ \\
\hline Higher salariat class network resources & 2.31 & 1.9 & $0-7$ \\
\hline Lower salariat and routine class network resources & 2.10 & 1.6 & $0-6$ \\
\hline Working-class network resources & 2.78 & 1.9 & $0-7$ \\
\hline \multirow[t]{2}{*}{ Age } & 33.50 & 7.9 & $18-49$ \\
\hline & $\mathrm{N}$ & $\%$ & \\
\hline \multicolumn{4}{|l|}{ Social Class Position } \\
\hline Non-salariat class & 3191 & 68.4 & \\
\hline Salariat class & 1476 & 31.6 & \\
\hline \multicolumn{4}{|l|}{ Gender } \\
\hline Male & 2202 & 47.8 & \\
\hline Female & 2465 & 52.8 & \\
\hline \multicolumn{4}{|l|}{ Marital Status } \\
\hline Single & 1207 & 25.8 & \\
\hline Married or cohabiting & 3116 & 66.8 & \\
\hline Divorced & 344 & 7.4 & \\
\hline \multicolumn{4}{|l|}{ Ethnicity } \\
\hline Dutch & 2324 & 49.8 & \\
\hline First generation Moroccan & 712 & 15.3 & \\
\hline Second generation Moroccan & 261 & 5.6 & \\
\hline First generation Turkish & 718 & 15.4 & \\
\hline Second generation Turkish & 268 & 5.7 & \\
\hline First generation non-western immigrant & 132 & 2.8 & \\
\hline Second generation non-western immigrant & 58 & 1.2 & \\
\hline First generation western immigrant & 78 & 1.7 & \\
\hline Second generation western immigrant & 116 & 2.5 & \\
\hline \multicolumn{4}{|l|}{ Educational Attainment } \\
\hline Primary or no education & 275 & 5.9 & \\
\hline Lower secondary education & 1751 & 37.5 & \\
\hline Higher secondary education & 1463 & 31.4 & \\
\hline Tertiary education & 1178 & 25.2 & \\
\hline Sample $4(\mathrm{~N}=4292)$ & $\mathrm{N}$ & $\%$ & \\
\hline \multicolumn{4}{|l|}{ Self-Rated Health } \\
\hline Poor & 79 & 1.8 & \\
\hline Fair & 466 & 10.9 & \\
\hline Good & 1990 & 46.4 & \\
\hline Very good & 1216 & 28.3 & \\
\hline Excellent & 541 & 12.6 & \\
\hline
\end{tabular}




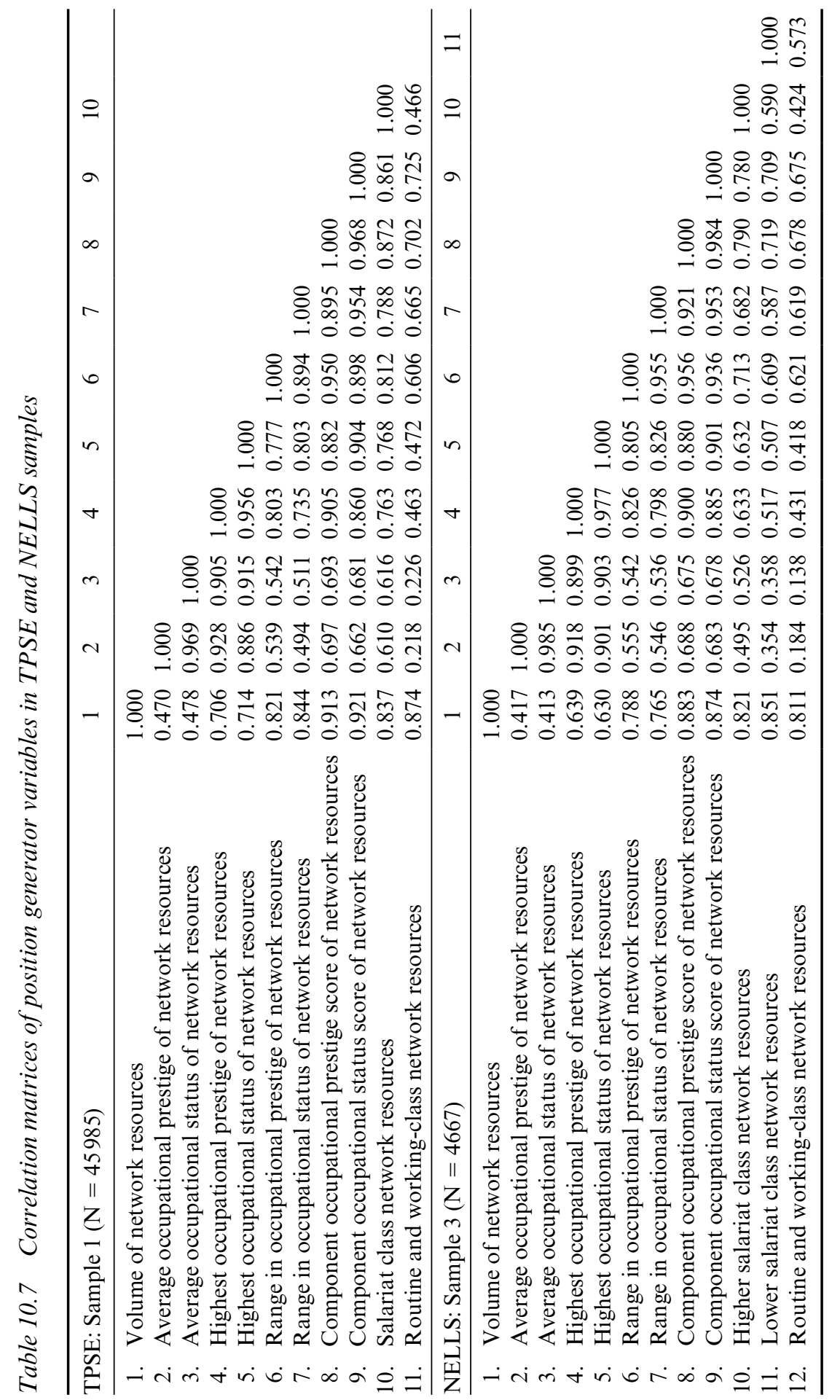

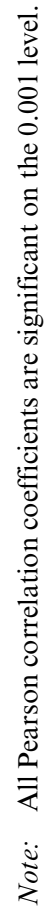




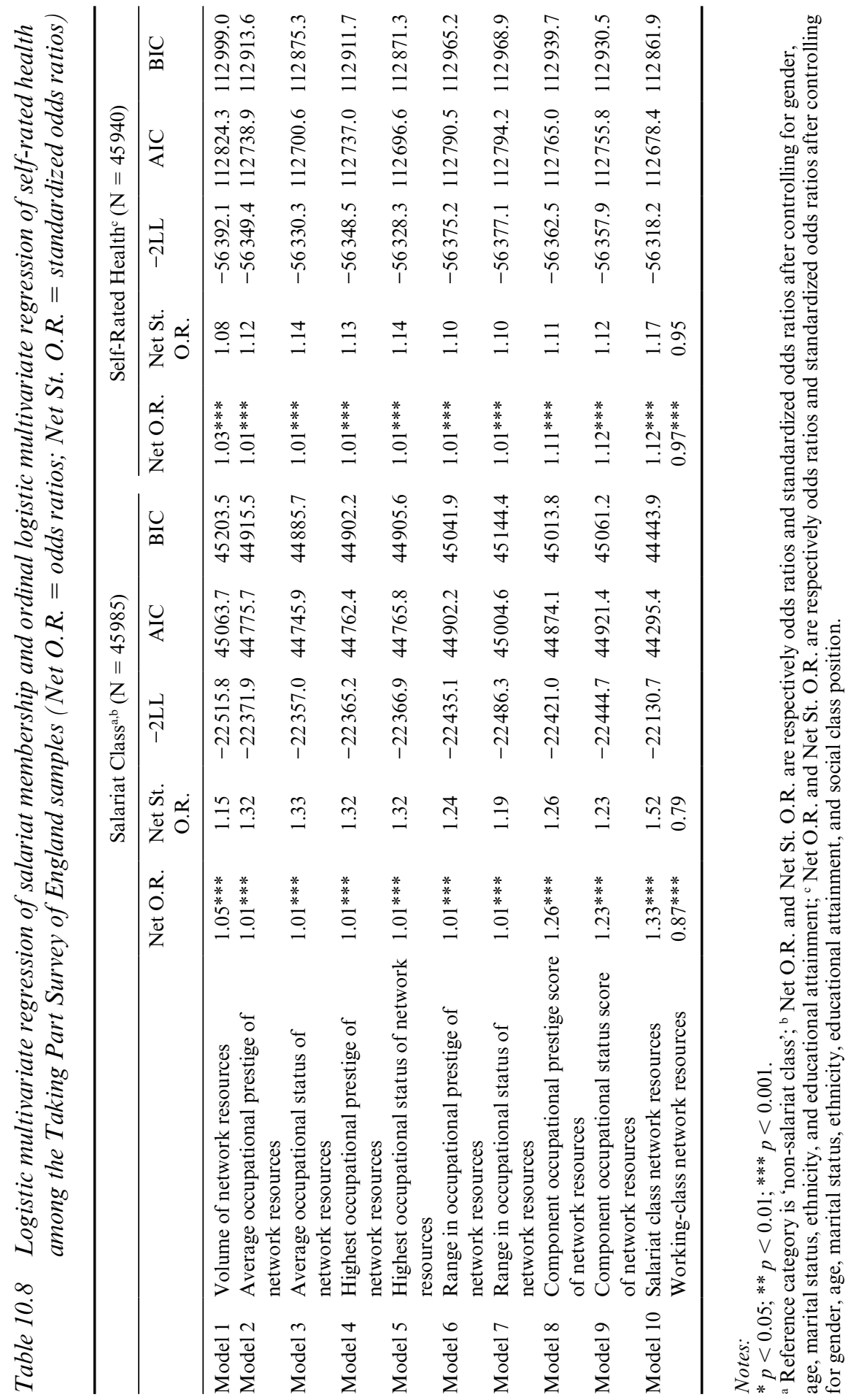




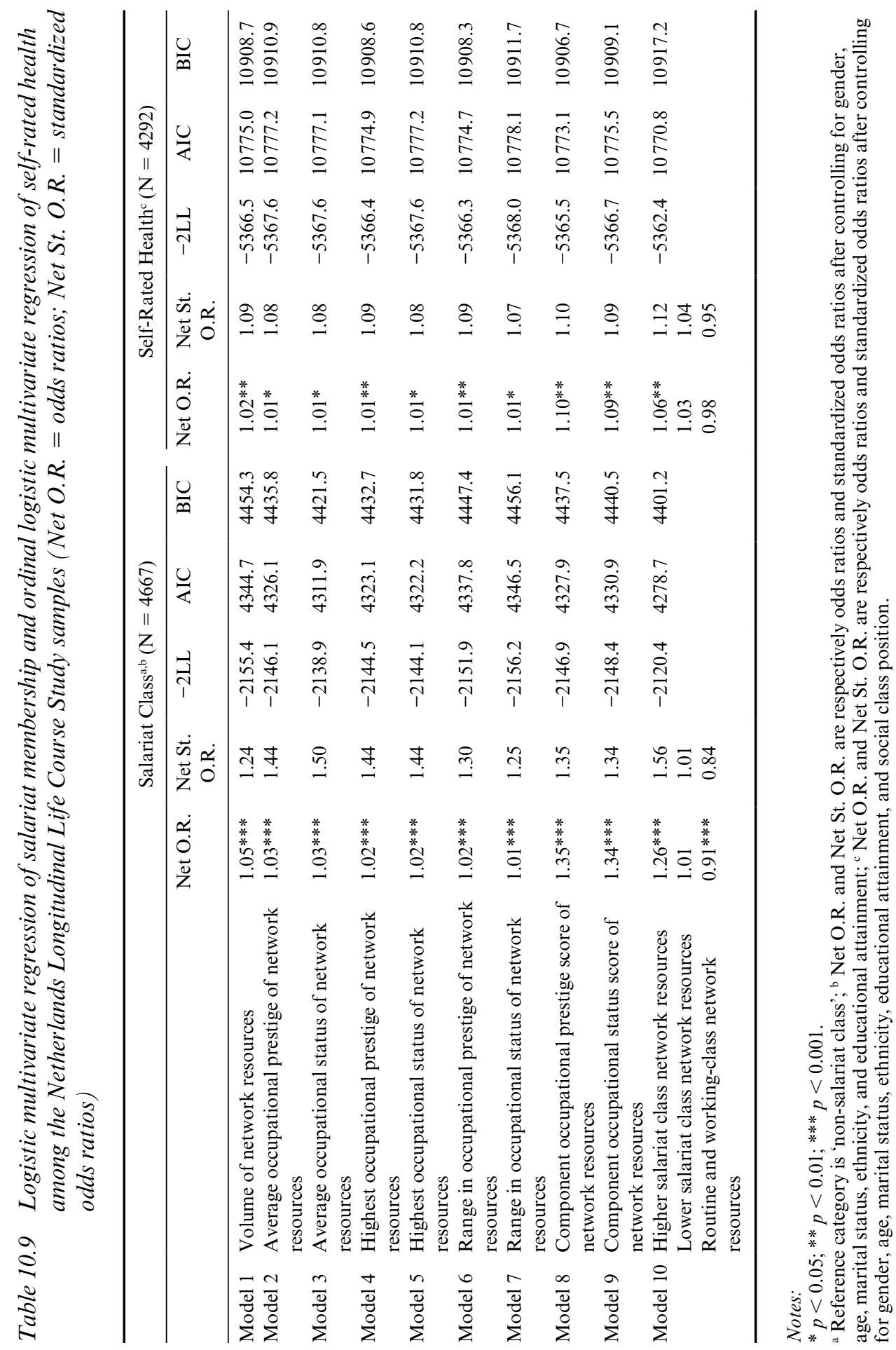


class-based position generator variables have a markedly better goodness of fit than the other models, followed by models with the average and the highest occupational prestige/status variables.

The data on the associations between social capital and self-rated health are shown in Tables 10.8 and 10.9. We again see that almost all position generator variables are positively associated with reporting better health, after controlling for the socio-demographic factors in the models (net odds ratios $>1$ ). People with more network resources, with network resources with a high average and highest occupational prestige/status, with heterogeneous network resources, and with network resources from the higher salariat class are more likely to have better self-rated health. However, English people who know more people from the working class are less likely to report better health (net odds ratio is 0.91 ). In the Dutch sample, this position generator variable is also negatively, though not significantly, related to self-rated health. The standardized odds ratios show that the strongest association between social capital and self-rated health is found when social capital is measured as knowing people with (higher) salariat class occupations. The second strongest associations are found with the average occupational status and highest occupational status-variables. The Akaike and Bayesian Information Criteria values provide further evidence for these findings. In both samples, the models with the classbased position generator variables have a better goodness of fit than the other models, followed by the models with the average and the highest occupational prestige variables. The exception is the BIC values for the models on self-rated health among the Dutch sample, which show the worst goodness of fit of the model with the class-based position generator variables.

\section{DISCUSSION AND CONCLUSION}

In this study, we gave an overview of six theoretically inspired types of position generator measures, tracked their popularity over time, and empirically examined whether using different measures will result in different findings empirically. In the last regard, we used two large-scale surveys and two general research topics (socioeconomic attainment and health).

We have shown that the six types of position generator measures differ from each other in their conceptualization of social capital and in their perspective on social stratification. The most popular position generator measure is the 'volume of network resources', which does not differentiate between network resources and simply counts the total number of accessed occupational positions. Next in the popularity charts are four types of position generator measures, which share the practice to differentiate between network resources in terms of occupational prestige or status. In so doing, they entail a functionalist perspective on social stratification. They differ from each other in the way in which they conceptualize social capital. While two of them measure status, namely, the highest and the average (mean) prestige/status of network resources, the other two focus on the network heterogeneity (range in occupational prestige/status) and the social capital multidimensionality (occupational prestige/status component scores). Finally, the least popular are the class-based position generator measures. They follow the idea that qualitative distinctions should be made between different kinds of network

\section{File supplied to Li - Not for distribution}


resources because the resource allocations in societies go along class cleavages with conflicting class relationships as a consequence.

In the second part of the chapter, we have examined whether using different position generator measures results in different associations of social capital with social class position and self-rated health. For these purposes, we used the Taking Part Surveys of England, and the Netherlands Longitudinal Life Course Study. In line with previous studies (Lin and Dumin, 1986; Erickson, 1996; Völker and Flap, 1999; Li et al., 2008; Song and Lin, 2009; Moore et al., 2011; Verhaeghe et al., 2012), we have found positive associations of several position generator variables with the class position and with selfrated health in both samples. People with many, diverse and socioeconomically advantageous network resources are more likely to find themselves in salariat occupations and to report better health. In addition, with the class-based position generator measures, a few negative effects of social capital were revealed too. It appears that knowing more people with working-class occupations is negatively associated with having a salariat class position, which confirms the strong degrees of class homogeneous relationships in society (McPherson et al., 2001; Li et al., 2008). Moreover, in the English sample, we found that knowing more working-class people is associated with worse self-rated health, which is in line with previous findings in Belgium (Verhaeghe et al., 2012) and England (Verhaeghe and Tampubolon, 2012). These findings corroborated the ideas of Portes (1998) and Moore and his colleagues (2009) that social capital may have negative contagion effects.

With respect to the main aim of this study, we found that using different position generator measures results in different findings. Comparisons between standardized odds ratios and Akaike and Bayesian information criteria suggest that the associations of social capital with class position and self-rated health are most pronounced when class-based position generator measures are used, followed by the highest and the mean prestige/status measures. Moreover, the class-based position generator measures reveal negative effects of certain types of social capital too, which are hidden with the other position generator measures. This is probably due to the categorical distinctions in the class-based measures made in network resources, whereas the other position generator measures are more continuous in nature. Because of these categorical distinctions different kinds of social capital effects, both positive and negative, can be detected.

These findings should, however, be seen within the confines of data sources used. First, because of the cross-sectional data we have to be cautious about the causality of the associations. It could be argued, for example, that people with bad health participate less in social life and have fewer opportunities to meet people and to acquire social network resources. Nevertheless, a reversed causality does not alter the relative strengths of the associations that are found. Secondly, the position generator instrument of the Taking Part Surveys of England was based on only 11 occupational items, while it is recommended to choose at least 15 occupational items (Erickson, 2004). Because of this low number of items, the findings could be less reliable.

From both substantive and methodological points of view, we recommend using the class-based position generator measures over and above the other measures for several reasons. First, as we demonstrated in this study, class-based position generator measures result in more salient (both positive and negative) associations with class position and self-rated health and can, consequently, be assumed to better capture social reality.

\section{File supplied to Li - Not for distribution}


Secondly, research by Verhaeghe and his colleagues (2013a) has shown that the reliabilities across different occupational lists are higher for most class-based position generator measures than for occupational prestige/status-based measures. The exception is the volume-measure, which has the highest reliability. Finally, most position generator measures based on occupational prestige/status have unpractical statistical features, such as high correlations and skewed distributions (Van der Gaag, 2005), which are difficult to handle in multivariate analyses. In contrast, the class-based position generator measures are only moderately correlated count variables which can easily be treated using Poisson or negative binomial regression methods. They share this characteristic again with the volume-measure. Nevertheless, the advantage of using class-based position generator measures over the volume-measure is that they distinguish between different network resources and consequently better grasp social realities.

In its network resources approach, social capital is seen as the resources embedded in social networks that can be mobilized for personal purposes (Bourdieu, 1986; Portes, 1998; Völker and Flap, 1999; Lin, 2001; Li, 2010). The fundamental question is in which way the social distribution of these network resources should be conceptualized. Do they follow a continuous distribution in terms of status or prestige, or a categorical distribution in which different kinds of resources are distinguished? As we have demonstrated in this chapter, the class-based measure, although the least popular, actually provides the most promising future for analysis in this field.

\section{NOTE}

1. We did not include the position generator measure 'total occupational prestige/status of network resources' in our review because only four studies used this measure. This measure is calculated by summing the occupational prestige/status scores of all accessible occupations.

\section{REFERENCES}

Abel, T. and K.L. Frohlich (2012), 'Capitals and capabilities: linking structure and agency to reduce health inequalities', Social Science \& Medicine, 74(2), 236-44.

Angelusz, R. and R. Tardos (2008), 'Assessing social capital and attainment dynamics: position generator applications in Hungary', in N. Lin and B. Erickson (eds), Social Capital: An International Research Program, Oxford: University Press, pp. $394-419$.

Aust, R.A. and L. Vine (eds) (2007), Taking Part: The National Survey of Culture, Leisure and Sport, London: Department for Culture, Media and Sport.

Bourdieu, P. (1986), 'Forms of capital', in J. Richardson (ed.), Handbook of Theory and Research for the Sociology of Education, New York: Greenwood, pp. 241-58.

Carpiano, R.M. and P.W. Hystad (2011), "Sense of community belonging” in health surveys: what social capital is it measuring?', Health \& Place, 17(2), 606-17.

Cockerham, W.C. (2005), 'Health lifestyle theory and the convergence of agency and structure', Journal of Health and Social Behavior, 46(1), 51-67.

Côté, R. and B. Erickson (2009), 'Untangling the roots of tolerance: how forms of social capital shape attitudes toward ethnic minorities and immigrants', American Behavioral Scientist, 52(12), 1664-89.

Crompton, R. (2008), Class and Stratification, Cambridge: Polity Press.

Davis, K. and W. Moore (1945), 'Some principles of stratification', American Sociological Review, 10, $242-9$.

De Graaf, P., M. Kalmijn, G. Kraaykamp and C. Monden (2010a), The Netherlands Longitudinal Lifecourse Study (NELLS): Dataset, Nijmegen: Tilburg University and Radboud University.

De Graaf, P., M. Kalmijn, G. Kraaykamp and C. Monden (2010b), Design and Content of the Netherlands

\section{File supplied to Li - Not for distribution}


Longitudinal Lifecourse Study (NELLS): Research Report, Nijmegen: Tilburg University and Radboud University.

Duncan, O.D. (1961), 'A socioeconomic index for all occupations', in A.J. Reiss (ed.), Occupations and Social Status, New York: Free Press.

Elliott, J. (2001), 'Referral hiring and ethnically homogeneous jobs: how prevalent is the connection and for whom?', Social Science Research, 30, 401-25.

Enns, S., T. Malinick and R. Matthews (2008), 'It's not only who you know, it's also where they are', in N. Lin and B. Erickson (eds), Social Capital: An International Research Program, Oxford: University Press, pp. 255-81.

Erickson, B. (1996), 'Culture, class, and connections', American Journal of Sociology, 102(1), 217-51.

Erickson, B. (2004), A Report on Measuring the Social Capital in Weak Ties, Toronto: Department of Sociology, University of Toronto.

Field, J. (2008), Social Capital, 2nd edn, Abingdon: Routledge.

Ganzeboom, H. and D. Treiman (1996), 'Internationally comparable measures of occupational status for the 1988 International Standard Classification', Social Science Research, 25, 201-39.

Ganzeboom, H., P. De Graaf and D. Treiman (1992), 'A standard international socio-economic index of occupational status', Social Science Research, 21, 1-56.

Goldthorpe, J.H. (1987), Social Mobility and Class Structure in Modern Britain, Oxford: Clarendon Press.

Green, G., L. Tigges and D. Diaz (1999), 'Racial and ethnic differences in job-search strategies in Atlanta, Boston, and Los Angeles', Social Science Quarterly, 80, 263-78.

Han, S., H. Kim and H.S. Lee (2012), 'A multilevel analysis of social capital and self-reported health: evidence from Seoul, South Korea', International Journal for Equity in Health, 11(3).

Kawachi, I. and L.F. Berkman (2001), 'Social ties and mental health', Journal of Urban Health, 78(3), $458-67$.

Li, Y. (2010), 'Measuring social capital: formal and informal activism, its socio-demographic determinants and socio-political impacts', in M. Bulmer, J. Gibbs and L. Hyman (eds), Social Measurement through Social Surveys: An Applied Approach, Farnham, UK: Ashgate Publishing, pp. 173-94.

Li, Y., M. Savage and A. Pickles (2003), 'Social capital and social exclusion in England and Wales (19721999)', British Journal of Sociology, 54(4), 497-526.

Li, Y., M. Savage and A. Warde (2008), 'Social mobility and social capital in contemporary Britain', British Journal of Sociology, 59(3), 391-411.

Lin, N. (1982), 'Social resources and instrumental action', in P. Marsden and N. Lin (eds), Social Structure and Network Analysis, Beverly Hills: Sage, pp. 131-45.

Lin, N. (1999), 'Social networks and status attainment', Annual Review of Sociology, 25, 467-87.

Lin, N. (2001), Social Capital: A Theory of Social Structure and Action, Cambridge: Cambridge University Press.

Lin, N. and M. Dumin (1986), 'Access to occupations through social ties', Social Networks, 8, 365-85.

Lin, N. and B. Erickson (2008), 'Theory, measurement, and the research enterprise on social capital', in N. Lin and B. Erickson (eds), Social Capital. An International Research Program, Oxford: University Press, pp. 1-26.

Lin, N., Y. Fu and R. Hsung (2001), 'The position generator: measurement techniques for investigations of social capital', in N. Lin, K. Cook and S. Burt (eds), Social Capital: Theory and Research, New Brunswick: Transaction Publishers, pp. 57-81.

McDonald, S., N. Lin and D. Ao (2009), 'Networks of opportunity: gender, race, and job leads', Social Problems, 56, 385-402.

McPherson, M., L. Smith-Lovin and J.M. Cook (2001), 'Birds of a feather: homophily in social networks', Annual Review of Sociology, 27, 415-44.

Moore, S., M. Daniel, C. Paquet, L. Dubé and L. Gauvin (2009), 'Association of individual network social capital with abdominal adiposity, overweight and obesity', Journal of Public Health, 31(1), 175-83.

Moore, S., U. Bockenholt, M. Daniel, K. Frohlich, Y. Kestens and L. Richard (2011), 'Social capital and core network ties: a validation study of individual-level social capital measures and their association with extraand intra-neighborhood ties, and self-rated health', Health \& Place, 17(2), 536-44.

Portes, A. (1998), 'Social capital: its origins and applications in modern sociology', Annual Review of Sociology, 24, 1-24.

Savage, M., Y. Li and G. Tampubolon (2006), 'Rethinking the politics of social capital: challenging Tocquevillian perspectives', in R. Edwards, J. Franklin and J. Holland (eds), Assessing Social Capital: Concept, Policy and Practice, Newcastle, UK: Cambridge Scholars Press, pp. 70-94.

Song, L. (2011), 'Social capital and psychological distress', Journal of Health and Social Behavior, 52(4), 478-92.

Song, L. and N. Lin (2009), 'Social capital and health inequality: evidence from Taiwan', Journal of Health and Social Behavior, 50(2), 149-63.

Treiman, D. (1977), Occupational Prestige in Comparative Perspective, New York: Academic Press.

\section{File supplied to Li - Not for distribution}




\section{Handbook of research methods and applications in social capital}

Van der Gaag, M. (2005), Measurement of Individual Social Capital, Groningen: Rijksuniversiteit.

Van der Gaag, M., T. Snijders and H. Flap (2008), 'Position generator measures and their relationship to other social capital measures', in N. Lin and B. Erickson (eds), Social Capital. An International Research Program, Oxford: University Press, pp. 27-48.

Verhaeghe, P.P. and G. Tampubolon (2012), 'Individual social capital, neighbourhood deprivation and selfrated health in England', Social Science \& Medicine, 75(2), 349-57.

Verhaeghe, P.P., Y. Li and B. Van de Putte (2013b), 'Socio-economic and ethnic inequalities in social capital from the family among labour market entrants', European Sociological Review, 29(4), 683-94.

Verhaeghe, P.P., B. Van de Putte and H. Roose (2013a), 'Reliability of position generator measures across different occupational lists: a parallel test experiment', Field Methods, 25(3), 238-61.

Verhaeghe, P.P., E. Pattyn, P. Bracke, M. Verhaeghe and B. Van de Putte (2012), 'The association between network social capital and self-rated health: pouring old wine in new bottles', Health \& Place, 18(2), 358-65.

Völker, B. and H. Flap (1999), 'Getting ahead in the GDR: social capital and status attainment under communism', Acta Sociologica, 42(1), 17-34.

Williams, J. (2007), Taking Part: England's Survey of Leisure, Culture and Sport (2006-2007), Technical Report, London: British Market Research Bureau (BMRB Limited).

Williams, J. (2008), Taking Part: England's Survey of Leisure, Culture and Sport (2007-2008), Technical Report, London: British Market Research Bureau (BMRB Limited).

\section{File supplied to Li - Not for distribution}

